\title{
The Effect of Fasting Ramadhan and Diet on Blood Sugar Levels in People With Diabetes Mellitus : A Literature Review
}

\author{
${ }^{1}$ Suherman, ${ }^{2}$ Rehan Aula Salsabila, ${ }^{3}$ Andriyani Asmuni, ${ }^{4}$ Dihartawan, ${ }^{5}$ Munaya Fauziah, \\ ${ }^{6}$ Triana Srisantyorini, ${ }^{7}$ Najwa Khairina, ${ }^{8}$ Dina Rahma Fadlilah \\ ${ }^{1-7}$ Faculty of Public Health, Muhammadiyah University of Jakarta \\ K.H. Ahmad Dahlan Street, Ciputat, South Jakarta, 15419, Indonesia \\ Email: rehanabilasals@gmail.com
}

\begin{abstract}
Diabetes mellitus is a health disorder caused by an increase in blood sugar levels due to insulin resistance. Fasting can be used as a way to control diet, when fasting calories in the body will be reduced and the body will break down glycogen into glucose so that glucose levels can decrease. The purpose of this paper is to determine the effect of Ramadan fasting and eating patterns on blood sugar levels in people with diabetes mellitus. The method used with the literature review is by reviewing several journals about the effect of fasting Ramadan and diet on blood sugar levels in people with diabetes mellitus. The results of this paper show that fasting has a significant effect on reducing blood sugar levels in Diabetes Mellitus patients. Decreased blood sugar levels are also influenced by diet. The conclusion of this writing shows that there is an influence on the decrease in blood sugar levels in people with diabetes mellitus who carry out Ramadan fasting. Then in the relationship between eating patterns, there is a relationship between diet and the incidence of diabetes.
\end{abstract}

Keywords: Fasting, Diet, Blood Sugar Levels, Diabetes Mellitus 


\section{INTRODUCTION}

Diabetes Mellitus (DM) is a health disorder in the form of a collection of symptoms caused by increased blood sugar (glucose) levels due to a lack of insulin resistance. Dm is currently a major growing problem, evidenced by a report from the International Diabetes Federations (IDF) stating the prevalence of people with DM disease in the world is 425 million population and will increase to 629 million population by 2045 . The number of people with diabetes is estimated at the age of 20-79 people (United Nations Population Division IDF, 2017).

DM disease reaches 158.757 million people. Indonesia ranks 6th in the country with the most diabetic population worldwide with 10,267.1 million DM people (IDF Atlas, 2017). According to Riskesdas (2013), diabetics accounted for $4.2 \%$ of deaths in the city (15-44 years) and made the death rate number 2 in the age group (45-54 years) in urban areas with a percentage of $14.7 \%$ in 2007 . The increase in the number of people with diabetes mellitus that occurs consistently shows that diabetes mellitus is a health problem that needs special attention in public health services.

A modern lifestyle with many food choices and a less healthy way of life lead to an increase in the number of degenerative diseases. Diabetes mellitus is one of these degenerative diseases (Krisnatuti, 2008). Lifestyle in urban areas with a diet high in fat, salt and sugar, resulting in people tending to consume food in excess, in addition, the diet of food that is instant is currently very popular by some people in addition to it tastes good but increases blood sugar levels (Suiraoka, 2012). For blood sugar levels to be more stable, it is necessary to set a regular eating schedule.

Fasting in the sense of language is restraining. In Islam fasting is an activity or activity of worshiping the Creator by refraining from food, drink, lust, and other activities since sunrise or dawn. Fasting can neutralize toxins and substances buried in gastrointestinal tracts, kidney organs, and other organs caused by preservatives, dye solutions, artificial sweeteners, cigarette smoke, which accumulate over the years (Albiby in Liza, 2009).

One of the fasts that must be carried out by Muslims is no exception for dm sufferers, namely Ramadan fasting. Ramadan fasting is a situation that can trigger the unstable status of diabetes and acute complications in the form of hyperglycemia, hypoglycemia, diabetic ketoacidosis coma, dehydration, and thrombosis that force sufferers into the hospital (Salti et.al 2004). Complications due to Ramadan fasting are more caused by changes in the number of calories consumed, a less frequent eating schedule, a range of not eating too long, lack of fluid intake, and inappropriate doses and medication schedules. During fasting, people with DM have a more patterned eating schedule that is two large portions at the time of sahur and breaking the fast (Yosephine, 2002). Eating planning or regulating diet in patients with diabetes mellitus is very important to note, one way to control diet is fasting. Because fasting itself has many benefits for the body. Because at the time of fasting calories in the body will be reduced and the body will break down glycogen into glucose (Salim, 2007). 
Several studies have been conducted by the American Diabetes Association Scientific Session relating to fasting have obtained results on the benefits of fasting and the health of the body provides good effects, including health problems such as type II diabetes. A person who experiences high blood sugar Chromis can stay away from the risk of complications by fasting gradually to stabilize blood sugar levels in the body. While the results of other research showed that blood glucose levels in diabetic Mellitus who fast during Ramadan decreased significantly compared to before Ramadan (Bener \& Yousafzai, 2014).

Based on this description, judging from the results of previous research. The author is interested in knowing the influence of Ramadan fasting and diet on blood sugar levels in people with Diabetes Mellitus.

\section{METHOD}

This article is a literature review article or review literature by review from several journals published from 2013 - 2019 on the Effect of Ramadan Fasting and Diet on Blood Sugar Levels in Diabetes Mellitus Patients downloaded through the https://scholar.google.id website and conducted for 2 Weeks, from April 14 to 24, 2020.

\section{RESULTS AND DISCUSSIONS}

Based on research conducted by Alfin et al in June 2019 on the Effect of Ramadan Fasting on Blood Sugar Levels in Patients with Type 2 Diabetes Mellitus found that fasting has positive benefits for people with Diabetes mellitus that can lower blood sugar to be more stable. This study used quasi methods of pre and post-test experiments with the design of a control group with a sample number of 36 respondents in patients of Purwakarta City Health Center in West Java. The results of the study with independent statistical tests showed a value of $\mathrm{p}=0.039, \mathrm{t}=2.147, \mathrm{p}<0.005$ so it can be concluded that there is a meaningful difference in blood sugar levels after fasting Ramadan in the intervention group and control group.

According to research conducted by Dolongseda et al in November 2016 on the Relationship of Physical Activity Patterns and Diet With Blood Sugar Levels In Patients with Type Ii Diabetes Mellitus in Poly Disease In Hospital Pancaran Kasih Gmim Manado found that there is a relationship between a diet with blood sugar levels in patients with diabetes mellitus. This study used descriptiveanalytical methods with a cross-sectional design with a sample number of 75 people. The results of this study are based on Pearson correlation test values obtained $p$-value $=<0,000$ which means that there is a relationship between diet and blood sugar levels in diabetic Mellitus patients.

From research conducted by Fatmaningrum et al in May 2017 on the Effect of Fasting Sunnah Monday Thursday on Blood Glucose Levels In Patients With Type 2 Diabetes Mellitus in Puskesmas 
Berbah, Sleman, Yogyakarta found that there is an effect of fasting on the decrease in blood glucose levels. The study used experimental quasi methods with pre-draft and post-tests with control group designs with a sample of 53 respondents. The results of this study showed that the independent T-test obtained a $p$-value $=0.04$ so it can be concluded that there is an influence between fasting on blood glucose levels.

Based on the results of research conducted by Sumangkut et al in June 2013 on the Relationship of Diet With the Incidence of Type-2 Diabetes Mellitus in Poli Interna Blu. Government General Hospital Prof. Dr. R. D. Kandou Manado found that there is a relationship between diet and the incidence of diabetes mellitus. The study used an analytic descriptive method with a crosssectional design with a sample of 80 people. The results of the study obtained a value of $p=0.00$ $(\mathrm{p}<0.05)$ showed that there is a relationship between diet and the incidence of Diabetes Mellitus.

Saputra et al researched in April - May 2016 on the effect of Fasting Monday and Thursday on Blood Sugar Levels When In People with Type 2 Diabetes Mellitus in Dukuh Kasihan, Bantul, Yogyakarta found that Fasting has the potential to lower blood sugar levels. The study used quasi pretest and post-test experiments with a control group design with a sample of 30 people. Based on the results of the study with the Independent T-test, a significance value of $p=0.031$ was obtained in the analysis of blood sugar differences between the experimental group and the control group after the intervention. The value of $\mathrm{p}<0.05$ can be said that there was a significant difference in blood sugar levels when between the experimental group that had been fasting and the control group that did not fast.

Ramadan fasting or Shiyaam is one of the elements in the Pillars of Islam. In the Qur'an surah Al-Baqarah:183-184 which means: O you who believe, it is obligatory upon you (to do) fasting as was required (also) on those before you that you fear, (i.e.) in a certain few days. The word Fardlu (obligatory) is what is then popularized and standardized in the books of jurisprudent when talking about the fasting chapter of Ramadan, with the mandatory understanding according to the law, namely: the commandment that must be done, with the provision that if the command is not obeyed or done, then the one who does it gets a reward; and if it is not obeyed or not done, then he will get sin (H Sulaiman Rasjid, Islamic Fiqh, 1990: 17).

People respond to the obligation of Ramadan fasting by understanding more deeply what the nature of Ramadan fasting is. As already mentioned above, this so-called Ramadan fast is the meaning of Shiyaam. According to TM Hasbi Ash-Shiddieqy the word Shiyaam sederivasi is the word Shaum which means restraint (Q.s. Maryam [19]: 26). The scholars of Syara' meaning Shiyaam is commensurate with the word Imsaak which when translated also as restraint, restraint. According to the term, the combination of shaum and imsaak can be interpreted: making a temporary distance 
(against something). The creation of such distances there are time limits and some ways are following the ability and durability of normal humans.

In terms of physical, the stomach is a place to digest food and drinks that enter it. The results of the digestion are for the health purposes of the body and to replace the parts of the body that experience wear (the cells die and need to be replaced). Proper eating is eating and drinking as well as health needs and replacement needs of cells that wear out. But this normal size is very often confused by excessive desire or appetite. This is where Shiyaam which means making a temporary distance between a person and eating-drinking that is being faced is very helpful to break it. If the principle of shiyaam is achieved, then the work of digestion becomes normal and the health needs and replacement of the body's cells run as they should (Damami, 2012).

It is not strange if fasting can nourish the body. Health experts also agree that fasting can cleanse all toxins in the body. From the Hadith narrated by Bukhari said that His Majesty the Prophet Muhammad (peace be upon him) said, "Fast you, you will be healthy (El-Jaquena, 2018).

Based on 5 journals that have been studied, it was found that fasting has a meaningful influence on the decrease in blood sugar levels in people with Diabetes Mellitus. The decrease in blood sugar levels is also influenced by diet, if the diet is not good it can increase blood sugar levels in the body, due to irregular eating frequency. One way to control diet can be done by fasting. Because fasting has many benefits for the body. Fasting helps glucose levels in the blood become more stable due to a more regular diet. The decrease in blood sugar levels during fasting is due to a decrease in insulin secretion.

\section{CONCLUSION}

There is an effect on the decrease in blood sugar levels in patients with Diabetes Mellitus who observe Ramadan Fasting. Then concerning diet, there is a relationship between diet and the incidence of diabetes.

It is recommended in people with diabetes mellitus with uncontrolled blood glucose levels to observe fasting and regulate their diet to help control blood sugar levels within normal limits. And it is expected that the results of this writing can be used as a medium of information to increase knowledge and motivate sufferers in fasting.

\section{REFERENCES}

Alfin, R., Busjra and Azzam, R. (2019) 'EFFECT OF RAMADAN FASTING ON BLOOD SUGAR LEVELS IN PATIENTS WITH TYPE II DIABETES MELLITUS', Journal of Telenursing (JOTING), 1, pp. 191-204.

Damami, M. (2012) 'AQIDAH ISLAM INNER ALIENATION THROUGH FASTING RAMADHA $N^{\prime}$ Available at http://m.muhammadiyah.or.id/id/8 content-192-det-aqidah- 
islam.htm (Accessed: April 24, 2020).

Dolongseda, F. V., Masi, G. N.M. and Bataha, Y.B. (2017) 'RELATIONSHIP OF PHYSICAL ACTIVITY PATTERNS AND DIET WITH BLOOD SUGAR LEVELS IN PATIENTS WITH TYPE II DIABETES MELLITUS IN POLY DISEASE IN HOSPITAL PANCARAN KASIH GMIM MANADO', e-journal Nursing,5, pp. 1-7.

Fatmaningrum, F. (2017) 'EFFECT OF SUNNAH FASTING ON THURSDAY ON BLOOD GLUCOSE LEVELS IN TYPE 2 DIABETES MELLITUS PATIENTS AT PUSKESMAS BERBAH, SLEMAN, YOGYAKARTA'.

Magiantang, J. S., Kepel, B. J. and Akili, R. H. (2015) 'THE RELATIONSHIP BETWEEN DIET AND THE INCIDENCE OF DIABETES MELLITUS IN LOBBO VILLAGE AND LOBBO I NORTH BEO DISTRICT OF TALAUD ISLANDS DISTRICT IN 2015', 653.

Santosa, A. (2014) 'CHARACTERISTICS OF CALORIE INTAKE AND BLOOD SUGAR IN DIABETICS II WHO FAST AND DO NOT FAST RAMADAN', Journal of IKESMA,10(Dm), pp. 22-30.

SAPUTRA, A.B. W. (2016) 'THE EFFECT OF FASTING MONDAY AND THURSDAY ON BLOOD SUGAR LEVELS WHEN IN PEOPLE WITH TYPE 2 DIABETES MELLITUS IN DUKUH KASIHAN, BANTUL, YOGYAKARTA NASKAH'.

Sumangkut, S., Supit, W. and Onibala, F. (2013) ' DIETARY ASSOCIATION WITH THE INCIDENCE OF TYPE-2 DIABETES MELLITUS IN POLY INTERNA BLU. RSUP. PROF. DR. R. D. KANDOU MANADO', e-journal Nursing, 1, pp. 1-6. 